\title{
Curly Hair Induced by Valproate in Bipolar Disorder
}

\author{
Görgülü Yasemin \\ Department of Psychiatry, School of Medicine, Trakya University, Edirne, Turkey
}

\section{TO THE EDITOR}

Hair loss or hair color change in patients taking valproate has been repeatedly reported. ${ }^{1-3)}$ However, drug-induced hair texture changes have been reported rarely. ${ }^{4}$ Curly hair is a very rare side effect of valproate. ${ }^{5)}$ Valproate is recommended for the acute treatment of mania and maintenance of bipolar disorder as a mood stabilizer. ${ }^{6}$ Valproate can be used also in the treatment of epilepsy. In a study of 250 patients, Jeavons et al. ${ }^{7}$ noticed five (2\%) patients developed curliness of the hair due to valproate. Wilting et al. ${ }^{5}$ described a 47 -year-old white female patient experiencing curling of the hair during treatment with valproic acid. There is no bipolar disorder patient whose hair curling with valproate, in the literature. I have noticed valproate induced curly hair in a patient with bipolar disorder. This is the only reported bipolar disorder case of a patient experiencing hair curling as a result of taking valproate. Written informed consent for publication was obtained from the patient.

The patient is 47 years old and has had a diagnosis of bipolar disorder for three years. She has experienced two manic episodes. She has been treated with valproate 1,000 $\mathrm{mg} /$ day for three years. At the sixth month of valproate usage, she noticed that her hair was getting curly. Her hair has remained curly. She has never had any perming of the hair performed. She doesn't describe any other hair-texture change. She prefers curly hair and doesn't want to change to another mood stabilizer. There isn't any other side effect of valproate in this patient. The patient reports that her treatment with valproate has gone well; however, she discontinued valproate in 2014 for a period of five months, resulting in a second manic episode. Her manic episode was managed by starting valproate again. Her hair remained curly whilst she refrained from taking valproate.

The mechanism of valproate induced effects on hair is unclear; however, it may be related to the effects of chelating of metals (copper, zinc, and magnesium) as well as inhibition of metallic enzymes. ${ }^{5)}$ Curling of the hair is an unusual side effect of valproate in bipolar disorder, so psychiatrists must inform patients about this side effect too.

\section{REFERENCES}

1. Gerstner T, Lipinski C, Longin E, König S. Valproate-induced change in hair color. J Am Acad Dermatol 2008;58 2 Suppl: S63-S64.

2. Chen B, Choi H, Hirsch LJ, Moeller J, Javed A, Kato K, et al. Cosmetic side effects of antiepileptic drugs in adults with epilepsy. Epilepsy Behav 2015;42:129-137.

3. Mieczkowski T, Tsatsakis AM, Kruger M, Psillakis T. The concentration of three anti-seizure medications in hair: the effects of hair color, controlling for dose and age. BMC Clin Pharmacol 2001;1:2.

4. Seckin D, Yildiz A. Repigmentation and curling of hair after acitretin therapy. Australas J Dermatol 2009;50:214-216.

5. Wilting I, van Laarhoven JH, de Koning-Verest IF, Egberts AC. Valproic acid-induced hair-texture changes in a white woman. Epilepsia 2007;48:400-401.

6. Yatham LN, Kennedy SH, Parikh SV, Schaffer A, Beaulieu S, Alda M, et al. Canadian Network for Mood and Anxiety Treatments (CANMAT) and International Society for Bipolar Disorders (ISBD) collaborative update of CANMAT guidelines for the management of patients with bipolar disorder: update 2013. Bipolar Disord 2013;15:1-44.

7. Jeavons PM, Clark JE, Harding GF. Valproate and curly hair. Lancet 1977;1:359.

Received: August 4, 2015 / Accepted: August 27, 2015

Address for correspondence: Görgülü Yasemin, MD

Department of Psychiatry, School of Medicine, Trakya University,

Balkan Yerleşkesi, 22030 Edirne, Turkey

Tel: +90-2842357641, Fax: +90-2842352730

E-mail: yasemingorgulu@yahoo.com

(a) This is an Open-Access article distributed under the terms of the Creative Commons Attribution Non-Commercial License (http://creativecommons.org/licenses/by-nc/3.0) which permits unrestricted non-commercial use, distribution, and reproduction in any medium, provided the original work is properly cited. 